\title{
A restricted fishing area as a tool for fisheries management: Example of the Capbreton canyon, southern Bay of Biscay
}

\author{
F. Sanchez ${ }^{a, *}$, G. Morandeau ${ }^{a}$, N. Bru ${ }^{b}$, M. Lissardy ${ }^{a}$ \\ a Ifremer Laboratoire Ressources Halieutiques Aquitaine RBE/HGS/LRHA, FED 4155 - MIRA, UFR Côte Basque, \\ Anglet, France \\ b Laboratoire de Mathématiques et de leurs Applications de Pau, UMR CNRS 5142, FED 4155 - MIRA, UNIV \\ PAU \& PAYS ADOUR, Pau, France \\ *: Corresponding author : Florence Sanchez, Tel.: +33229008598 ; fax: +33229008552 ; \\ email address : florence.sanchez@ifremer.fr ; fsanchez@ifremer.fr
}

\begin{abstract}
:
Marine Protected Areas (MPAs) are generally considered as one of the most important tools, among the many regulations, designed to preserve marine resources as well as enhance fisheries. In the southern Bay of Biscay, local French fishermen requested creation of a restricted area to help settle disputes between the various métiers operating there. This restricted area, which lies mainly in French waters, covers part of a deep submarine canyon off the French and Spanish coasts, known to have a large population of mature hake. This study aims to better understand the effects of a restricted area upon French fleets operating there, particularly upon three main métiers-longliners, gillnetters and trawlers. The study area includes three ICES statistical rectangles. The data, based upon reported landings and auctions sales for the period 1985-2008, were analyzed using multivariate analysis. The fishing activity is more important in one rectangle which includes the restricted area. Bottom longliners and gillnetters, operate mainly in this one while trawlers are less dependent. The first métier concentrates particularly on hake and the second has targeted other species and has become less dependent on hake. Trawlers target a wider range of species. Over the past ten years, the restricted area has contributed to maintain the fleets operating here. The border with Spain adds other constraints over the issue of access to regional fisheries and makes management a little more complicated.
\end{abstract}

\section{Highlights}

Effects of the regulation upon fleets operating in the Capbreton canyon are examined. The circumstances that led to a restricted area creation for gillnetters are showed. The access regulations to fishing areas have maintained the different métiers. The choice of restricted area location allowed the maintain of longliners.

Keywords: Bay of Biscay ; Restricted area ; Submarine canyon ; Economic dependence ; Métiers' dynamics 


\section{Introduction}

Fishery management is organized around regulations which concern fishing effort such as vessel number and their technical characteristics, gear prohibition, quotas, closed seasons and area restrictions. The European Union (EU) sets annual catch limits by species (TAC), and national quotas as well as minimum size species. It also issues fishing licenses, regulates mesh sizes and publishes Multi-Annual Guidance Programs under the Common Fisheries Policy (CFP). Specific national or regional licenses are also issued. Among management measures, Marine Protected Areas (MPAs) are increasingly important. They were introduced to protect local marine resources as well as enhance fisheries. However, because they are open to the effects of multiple uses and to external pollution [1], special attention must be paid to their selection if reserves are to be managed efficiently [2]. This concerns both their size and the fishing practices in place as well as specification of the particular protections objectives required. Although MPAs certainly improve fishing practices by promoting best practice and better conservation of biodiversity, their benefits are limited by their number and size [3]. While their role in the protection of species and habitats is clear [4], uncertainty in larval dispersal and adult biomass exportation makes it difficult to measure their full effect upon population and yield sustainability [5].

In France, other spatial management measures are used such as "Restricted Areas" which could be considered as a specific form of MPA. Created on the initiative of professional fishermen, these areas are delimited areas at sea, within which some particular types of fishing gear are temporarily or permanently prohibited in order to protect certain species and/or métiers (according to ICES - the International Council for the Exploration of the Sea - there are three types of fishing unit: the fleet, the fishery, and the métier. The last is defined by ICES as "groups of homogeneous fishing activity, targeting the same (assemblage of) species, using similar gear, during the same period of the year and within the same area" 
[6]). These restricted areas are set up either by ministerial decree (Order of the Ministry of

Public Works and Transport dated the 4th of June 1963) or come under prefectural legislation.

Today, there are 47 fishing restricted areas in French waters with 57\% located in the Atlantic coast [7].

The Bay of Biscay is a typical mixed fishery with a large variety of species exploited by a wide range of fishing gears such as trawls, longlines, gillnets, pots and dredges [8]. The presence of several métiers in the same area using different techniques has led to the need to regulate their use in the coastal zone. A restricted area was established near Spanish waters by prefectural legislation, at the request of local French fishermen prohibiting gillnet fishing. Most of it is under French control, the rest being within the Exclusive Economic Zones (EEZ). This cross-border location makes management complicated. The original aim was to resolve conflicts between two métiers (bottom longliners and gillnetters) targeting the same species such as hake. This is an old issue dating as far back as 1727 [9]. More important, this restricted area is located on a deep coastal canyon, the Capbreton Canyon, easily accessible by the different fleets.

This article seeks to better understand the circumstances that led to the restricted area creation and its effects upon French fleets operating in this area. Catch statistics together with a detailed description of regulatory events and minutes of discussions of the local fishing committee have been used to examine changes in fishing activities (vessels number, landings and turnover).

\section{Material and methods}

\subsection{Study area}

The southern part of the Bay of Biscay is characterized by a narrow shelf with a sandy bottom along the Landes plateau and a rocky littoral on the Basque coast. This region is 
crossed by the Capbreton canyon (Fig. 1a), which includes the restricted area studied in this paper.

This canyon is a submarine valley, classified as a "gouf" which begins less than 400

$\mathrm{m}$ from the shoreline and extends from east to west, parallel to the Spanish coast for over 250 $\mathrm{km}$. It is subjected to the combination of river plumes and ocean currents i.e. local upwellings and poleward coastal currents along Basque and North Aquitaine coast $[10,11,12]$. The

Capbreton canyon is active with a high amount of organic matter transported toward the abyssal plain $[13,14]$. The canyon "s geomorphological and hydrological characteristics favor species diversity and biological production of plankton and micronecton aggregations $[15,16]$, as well as megafaunal and scleractinian diversity $[17,18,19]$ and bird and marine mammal concentrations [20,21]. Several studies confirm that submarine canyons are highly productive, hosting a wide variety of benthic, demersal and pelagic fauna $[22,23,24]$.

Such conditions enhance local fishery production [23]. The Bay of Biscay is known to have the biggest nurseries of European hake with adult concentrations in canyons and on the rocky seabed of the shelf break area [25]. In the case of the Capbreton Canyon, the fishing grounds are very localized, particularly for European hake which is targeted by bottom longliners, gillnetters and trawlers.

This study focuses on the area containing this canyon and covers 3 statistical rectangles $15 \mathrm{E} 8,16 \mathrm{E} 8$ and $16 \mathrm{E} 7$ [surface $1^{\circ}$ longitude $\mathrm{x} 0,5^{\circ}$ latitude] located in the Bay of Biscay (ICES Division VIIIb and VIIIc). Hereafter, these rectangles are denoted R15E8, R16E8 and R16E7. The combination of these three statistical rectangles forms the study area. They delimit three zones with differing access for French and Spanish fleets. The area has a maritime border with Spain and Spanish territorial waters (representing 5.5\% of the studied area) which are inaccessible to French fleets.

\subsection{Fishing activity}


This maritime space is mainly characterized by pelagic and demersal fisheries.

114 targeting mackerels (Scomber scombrus, Scomber japonicus), sardine (Sardina pilchardus),

115 horse mackerel (Trachurus trachurus), anchovy (Engraulis encrasicolus) and tunas (Thunnus

116 alalunga, Thunnus thynnus). In terms of tonnage, pelagic species constitute the most

117 important landed fishes [26].

118 The gillnetters, longliners and bottom trawlers fish for demersal species such as hake

119 (Merluccius merluccius), monkfish (Lophius piscatorius and Lophius budegassa), sea bass

120 (Dicentrarchus labrax), common sole (Solea solea), turbot (Scophthalmus maximus) and

121 sparidean. In addition, potters target other benthic species such as large crustaceans (Cancer

122 pagurus, Homarus gammarus). Most of species as sole, hake, monkfish, anchovy...are managed by TAC - under the Common Fisheries Policy (CFP) of the European Union - and and since 2006 respectively to increase the spawning stock [8]. In 2008, about 118 French vessels and 350 fishermen were fishing in the study area. They landed $3190 \mathrm{t}$ of sea products for a total value of $3700 \mathrm{k} €[26,27]$. To increase income, 30-35 vessels sell directly to consumers (into 3 local ports: Capbreton, Bayonne, Saint-Jeande-Luz, see Fig. 1a), avoiding the whole sale market. The fleet consists mainly of single owner operators whose crews are paid under a "shared-wage" system. Bottom longliners

131 hake, gillnetters, pelagic and bottom trawlers represent around $79 \%$ of the total French fleet 132 operating in this area. Gillnets and longlines are considered as passive gears but pelagic and 133 bottom towed by boats are considered as active.

134 This study concentrates upon the main gear types used in the study area: bottom 135 longline, nets (gillnet and trammel net) and trawls (pelagic and bottom trawl). These represent 
about 93 boats in 2008: of which longliners represent 19\% of this total number, gillnetters $44 \%$, pelagic and bottom trawlers $37 \%$. Bottom longline hake fishing takes place at the edge of the Capbreton canyon. Gillnetters operating in the coastal area use several types of nets (gillnet and trammel) targeting several species. Coastal netters predominate in the sector although large netters are also present. Bottom trawlers operate mainly in the northern sector.

141 While fishing in the canyon itself is excluded both by topography and regulation, they are

142 able to work along the shelf break. The detailed characteristics of the métiers based on gear

143 dimension, location, yields and main target species are shown in table 1. System (SIH) of Ifremer. The data are based on landings (in weight) - of all vessels working at least once in these statistical rectangles - and upon whole sale market (in value). Two different datasets were compiled:

- The first (from official logbooks and catch reports) contains information on fishing

The study excludes results of 1999 due to a change in the data recording system which as Spanish data are not available. 
French professional fishermen are organized nationally and locally. There are the

163 National Committee of Marine Fisheries and Aquaculture (CNPMEM) as well as their

164 regional committee (in this case, CRPMEM Aquitaine) and their local office (in this case,

165 CIDPMEM Pyrénées Atlantiques Landes) ${ }^{1}$. Membership is mandatory for professionals.

166 Their committee members integrate all sea workers such as fishermen, ship-owners, others

167 representing fish traders and the processing industry. These committees are under the

168 authority of the French State. Their role is to improve coexistence between métiers and

169 includes allocation of fishing rights (licenses, quotas ...), supervision of fishing effort (gear

170 and authorized areas, fishing period...). The local fishing committee has a consultative role in

171 fisheries management applying regional decisions and making propositions about sensitive

172 issues in their circumscription that are forwarded to regional level.

\subsection{Access regulation}

The main legislation concerning the fishing practices in the area is summarized in

table 2 and involves the following levels of authority:

- European legislation requires vessels to report catches in their logbooks and also covers stock recovery plans;

- National legislation, presented in this article, adapts or adds to European directives;

- Regional regulations manage the various fishing practices and cover access to fishing grounds and the prohibition of certain types of gear. have been used [29].

\footnotetext{
${ }^{1}$ Those types of committees were created by Order n ${ }^{\circ} 4-1813$ of August 15, 1945.
} 
185 Spanish fishermen regarding access to and sharing of fishery resources as well as competition

186 for the same market [30,31] (despite signature of a fisheries agreement by both governments in 1967) [32].

Introduction of new gear or technology (for example the pelagic trawl in 1976 or the tuna driftnet in 1986) has led to improvements in catches and turnover. However, it has also resulted in sometimes violent confrontation between the "old" and the "new" métiers (for example, purse seine and pelagic trawl) over the same coveted fishing ground due to its effect upon particular species such as anchovy $[33,34]$.

Two examples of regulation access regarding the studied area are shown below. In the first case, bottom longliners requested closure of some areas to netters because they targeted the same species (hake) in the same area - the canyon - without any possibility of redeployment for the longliners. So, a restricted area was established in 1985 included in 4 rectangles R16E8, R17E8, R17E7 and R16E7 (by prefectoral order Ord. n40 March 5, 1985) prohibiting gillnet fishing in two (rectangular) sections of the canyon including a large part of the continental shelf, which had been traditionally exploited by longliners (Fig. 1a). From 1985 until 1999, the size of this restricted area was $1305 \mathrm{~km}^{2}$ (of which $1190 \mathrm{~km}^{2}$ lies in the study area). The greater part was located close to the coast with $21 \%$ inside the 6 nautical miles limit. Table 3 summarizes the prohibited maritime surface by gear in each studied rectangle. Net fishermen claimed that the restricted area and its location close to the coast strongly handicapped net fishing and caused shortfalls in their catches (Minutes No. 232 of March 17, 1986 - Local fishing committee currently called CIDPMEM Pyrénées Atlantiques Landes). Over the years, they have maintained pressure to obtain a revision of the regulation in this area. They succeeded in reducing this surface in 1999 , to $332 \mathrm{~km}^{2}$ with a location in R16E8 only: as shown in the figure $1 \mathrm{~b} 65 \%$ are in French territorial waters with $3 \%$ inside the 
6 nautical miles. A portion of the restricted area is also located in the EEZ: French regulations

210 do not apply to foreign vessels (mostly Spanish) which fish there.

211 In the second case, in addition to the national regulations prohibiting fishing within 3

212 nautical miles, netters obtained exclusion of trawlers within 6 miles of the coastline from

2131981 (by Order $n^{\circ} 88$ of April 27, 1981 and Order $n^{\circ} 21$ of February 8, 1993) due to

214 destruction of passive gear by towed gear. The cumulative effect of these regulations (see

215 Table 2) results in limited trawler access in part of the restricted area.

\subsection{Main indicators of fishing activity}

To better understand and better compare the métiers, a reference trip lasting ten hours was made, entitled hereafter "unit trip (UT)"was used. This choice is considered to be a typical trip for a coastal vessel.

Three families of indicators were retained:

- Fishing Activity Dynamic: the number of vessels and their distribution by rectangle (chosen because this reveals attractiveness of sectors), landings in weight by vessel and by crew member (tonnes vessel ${ }^{-1}$.crew ${ }^{-1}$ ); landings in weight by vessel and by UT (tonnes vessel $\left.{ }^{-1} \cdot 10 \mathrm{~h}^{-1}\right)$;

- Métier Accessibility: the theoretical maritime surface available expressed in percent by métier. This indicator is built from different regulations mapped in figures 1a and 1b. The spatial boundaries of each regulation were used to calculate the surface of regulated areas in $\mathrm{km}^{2}$. The percentage of maritime surface available for each métier ("Accessibility") is calculated using the information and the surface of the ICES rectangles.

- Economic Dependence upon sectors expressed in value: turnover by vessel and by crew member (in $\mathrm{k} €$ vessel $^{-1} \mathrm{crew}^{-1}$ ), turnover by vessel and by UT (in $\mathrm{k} € \mathrm{vessel}^{-1} 10 \mathrm{~h}^{-}$ 
$\left.{ }^{1}\right)$. To better understand the relationships between economic indicators, the percentage of turnover due to the main species has been added in order to highlight those fleets which are vulnerable through dependence upon few species [8].

\subsection{Statistical approaches}

An explanatory multivariate analysis e.g. normalized principal component analysis (PCA) has been applied to the dataset containing all indicators from the three families described above. It is performed using $\mathrm{R}$ packages RcmdR and FactoMineR [35]. Information about métiers and sectors is added as supplementary factors. All graphs contain variables with $\cos ^{2}>0.2$. Evolution of indicators is also presented in classical statistical graphs.

\section{Results}

\subsection{Distribution of vessels in the study area and evolution of the presence of main} métiers

The low activity level of bottom longliners in R16E7 is noticeable despite the fact that a part of the restricted area (which was reserved for them) was contained within this rectangle until 1985. In R15E8, the limited activity of a few bottom longliners varies between 4 to 9 vessels from one year to another during the study period.

The greatest proportion, more than $60 \%$, of total vessels are active within R16E8 (Fig. 2) which contains the restricted area, partially from 1985 to 1999 and entirely thereafter.

During the initial period from 1985 to 1998 (Fig. 3), the presence of each métier in the study area is equivalent in number of boats and trends are similar. For the second period, the number of vessels differs depending on the métier. Bottom longliners are the least represented

254 but their number grew significantly from 2 to 18 , between 2000 and 2008. Netters are greater 255 in number and increased from 20 to 41 between 2000 and 2008. The presence of pelagic 256 trawlers is very variable and the number of bottom trawlers remains stable on the second 
period. However, the number of gillnetters is twice as large as bottom longliners by 2008 (Fig. 3).

\subsection{Economic dependence according to spatial occupancy and fishing activity} criterion

The first three principal components coming from PCA give $37 \%$ of total inertia. This seems low but reveals few significant linear correlations between the chosen descriptors and emphasizes their variability from year to year.

Bottom longliners and gillnetters have a high turnover by vessel and by crew member in R16E8. Turnover, especially for bottom longliners, is highly dependent upon R16E8 and upon hake (Fig. 4a and Fig. 4b). Bottom trawlers ${ }^{e e}$ turnover hardly depends at all on R15E8 while sole contributes highly to the gillnetter"es tumover (Fig. 4b). Pelagic trawlers have high levels of landings and turnover by vessel by UT (Dim1) on R16E7 and a turnover strongly dependent on mackerel, bluefin tuna and albacore tuna (Fig. 4a).

Focusing on the sector R16E8 which contains the restricted area, one can notice that more than $75 \%$ of bottom longliners ${ }^{e e}$ annual turnover is generated by hake (Fig. 5a) with conger being the second most important contributor. Hake and sole contribute equally to gillnetters $^{\text {ee }}$ annual turnover during the first period. However, in the second period hake drops to the same level as gilhead sea bream and sea bass while sole remains stable (Fig. 5b).

Pelagic trawlers are less dependent on hake but more on the pelagic species such as anchovy and mackerel (Fig. 5c). For bottom trawlers, hake is the main contributor in the first period but this changes for the second period in favor of other species such as monkfish, squid and red mullet (Fig. 5d).

The evolution of turnover per boat and per crew member is shown for the main métiers in R16E8 (Fig. 6). In the first period, there was an equivalent turnover between gillnetters and pelagic trawlers while bottom longliners realized a high turnover (max. $25 \mathrm{k} €$ 
282

in 1991) before decreasing from 1992. Trends changed in the second period. Bottom longliners se turnover is equivalent to that of trawlers while gillnetters ${ }^{e e}$ tumover is higher than the others (between 15 and $20 \mathrm{k} €$ ). Bottom trawlers realized the lowest score.

\subsection{Quality and available data}

Different approaches are usually used to assess the effect of MPAs. Most studies concentrated on the ,effects on population or assemblages ${ }^{\text {ee }}$ or other topics such as fishing yields, indirect socioeconomic effects and ecological indirect effects [36]. These need data detailing results inside and outside the MPA or before and after its establishment [36,37,38]. In this study, the lack of statistical series by vessel before the establishment of the restricted area in 1985 did not allow modeling to simulate the consequences of its creation or to do a comparative empirical study before and after or inside/outside.

Although the first three years of the series are incomplete due to the small number of vessels submitting logbook information, the trends in reported catches do reflect the reality of fishing activity and match the evolution of the fishing fleet in the Bay of Biscay $[8,26,39]$.

\subsection{Fishermen conflicts}

The study area is subject to different types of fishing and in the past the use of different gears in the same fishing grounds has led to conflicts between fishermen. The restricted area was established to resolve conflicts between bottom longliners and gillnetters while sustaining the practice of bottom longline hake fishing. Its location on the canyon covers an area mainly exploited by bottom longliners due to the large presence of adult hake there. The surface of this box enclosure was reduced in 1999 at the request of gillnetters and trawlers. Generally, most conflicts focus on the active against the passive. For example in the Gulf of Mexico, the Fishery Management Council created a MPA to resolve conflict between shrimp and stone-crab fishermen [40]. However, in this case, two passive métiers oppose each other. Other MPAs, with such objectives as increased fishery yields, reduced fishing effort or 
ecological protection, have been implemented with varying degrees of success $[1,40,41]$. In

308 some cases, MPAs simply caused fishermen to move elsewhere rather than reduce the fishing

309 activity [42]. With a rights-based approach, Mascia and Claus [43] studied the consequences

310 of effort displacement during the creation of MPAs. These consequences are classified

311 according to the criteria: gained, lost and secured, which allowed assessing the equity of the

312 MPA. The dimensions considered are welfare, economic well-being, health, education, social

313 capital and culture. In this case study, the size of the restricted area for gillnetters, was too

314 large and was not well accepted, due to loss of fishermen's earnings. Consequently, they

315 obtained a reduction of the area. Since this took place, the competition to access this space has

316 been reduced and the conflict between longliners and gillnetters has been resolved. In the

317 same period, gillnetters took advantage of prohibited areas for trawlers inside 6 miles, by

318 having more space to spread their nets and to increase their own productivity (Table 2 and

319 Table 3). As mentioned above, the displacement of fishing effort can have economic, social

320 and environmental consequences. There are few analytical studies which quantify the impact

321 of these movements. The concentration of boats into areas outside restricted areas has the

322 potential to increase competition and conflict especially in a context of declining yields [44].

323 In this case study, trawlers could have been impacted by regulatory measures due to the

324 importance of the prohibited areas for them (around 17\%), but they could easily move

325 elsewhere; due to their size, they are able to operate in a wider area and also further offshore,

326 without creating new problems for other boats.

327 These examples show how each métier within the fisheries committee is able to

328 influence decisions. Conflicts of interest between committee members can lead to ad hoc

329 alliances aimed at influencing decisions in a direction more favorable to some than others and

330 that bargaining powers of different métiers (represented by elected fishermen and ship-

331 owners) can fluctuate greatly over time. 
333 fishing. It has since evolved into a significant shrinkage of the most important area for this

334 métier and in combination with other national regulations, has mainly released space for

335 netters. The geographic distribution of the various competitors ${ }^{\text {ee }}$ métiers has improved, thus

336 promoting better relations between them.

Although the management of this area was achieved gradually step by step rather than as the result of an elaborate plan, the end results appear satisfactory. Fishermen believe that without the restricted area, the métier of longliners would have disappeared (Minutes No. 232 of March 17, 1986 - Local fishing committee CIDPMEM Pyrénées Atlantiques Landes). over a wide coastal area has often caused the failure of MPA. They suggest it should be implemented with an ecosystem approach to optimize the result of MPA and to avoid creating new problems.

\subsection{Economic dependence}

The contribution of species to turnover differs according to métier. The results of PCA

348 demonstrate the high contribution of hake to bottom longliners ${ }^{\text {ee }}$ turnover. The same for

349 gillnetters although the common sole and others species are also important contributers. In the

350 Bay of Biscay, most fleets derive their main income from one or two species [8]. In this 351 analysis, more than $75 \%$ of bottom longliners ${ }^{e e}$ turnover comes from hake. Conger is the 352 second most important, especially during "bad" periods. This makes this métier highly 353 selective but more vulnerable because more sensitive to changes in targeted stock and in 354 prices. Many authors establish that small-scale fisheries are sustained by only a few species 355 and note that some fishing tactics are relatively "clean" with a clear target species 
representing most of the catch $[45,46]$. In this study, the increasing number of bottom

longliners in recent years with a turnover equal to that of other métiers, underlines this

métierees strength. The sustainability of the bottom longliner métier is also related to the status

of stocks. Hake stocks collapsed in 1980 and a recovery plan was finally agreed by the EU in 2002 (EC Reg. 494/2002). The increase of the Spawning Stock Biomass (SSB) observed since 2005 can explain that the bottom longliner métier again became more attractive as yields improved [47]. Price variation of species is also an important factor underlying the changes in value of landings $[39,48]$. The market crisis that occurred in France in the mid1990s led to a sharp drop in prices of the main landed species in the Bay of Biscay (including hake) between 1991 and 1994. In this study, the decrease observed in the number of bottom longliner vessels during the first period is probably attributable to the drop in hake prices which contribute such a high proportion of landing values.

Although the contribution of hake to the turnover of netters and trawlers has declined,

369 it has been offset by a change in strategy to capture other species. Consequently, the establishment of the restricted area does not seem to have affected their economic viability.

\section{Conclusion}

Suuronen et al. [41] emphasized that the MPAs in the Baltic Sea were implemented

373 without consulting the fishermen or heeding scientific advice. According to these authors, 374 there should have been better communication between fishermen and other stakeholder 375 groups. This would have resulted in sustainable harvest policies, before implementation of 376 any major management action. This study suggests that the restricted area is appropriately

377 located in the canyon for several reasons: (i) Fishermen were behind the proposal; (ii)

378 Emerging conflicts have been resolved through compromise between them (iii) Bottom

379 longliners operate mainly on the edge of the canyon and the choice of the restricted area 
location has enabled maintenance of this "emblematic" métier: which was already practiced

381 by Basque fishermen in the eighteenth century [9,49]; (iv) Today, local fishing committee

382 strongly support and publicize this métier and have begun a process of eco-labeling. Thus the

383 restricted area will enhance the traceability process; (v) It is located on a canyon known to be

384 a productive system with major adult hake concentrations (containing several localized

385 fishing grounds).

Moreover, the adoption by Authority of different regulations governing access to

387 fishing areas according to different métiers (often after consultations or stakeholders ${ }^{\text {ee }}$

388 proposals), has contributed to a better distribution of the fishing effort, thus promoting the

389 viability of different fleets. Other factors which must be taken into account to explain the

390 results of this study include the recovery plans for different halieutic stocks, the multi-annual

391 guidance programs (regulation of fishing effort) and indeed the market conditions.

Part of this restricted area is located in the EEZ (Fig. 1b) and French fishermen

complain about the presence there of foreign gillnetters who are permitted under the EU law

to use gear otherwise forbidden to the French. Indeed, the study area straddles the Spanish

border and approximately 175 Spanish coastal fleet vessels operate there. They also use a

wide range of gear during the year: handlines and trolling predominate (respectively $38 \%$ and $34 \%$ ), nets represent $29 \%$ whereas longlines are less used (14\% of vessel) [50].

In this context, in 2009, the local fishing committee requested application of the

399 French regulations to foreign vessels entering the EEZ part of the restricted area. The French

400 proposal was supported by the South Western Waters Regional Advisory Council

401 (SWWRAC) and is reinforced by another request of the Federation Cofradias from

402 Guipuzkoa (Regional Fishermen Guild Organization of the Basque country in Spain), which

403 represents the interests of the Spanish ship owners and fishermen [30]. This type of cross-

404 border fishery management had already been negotiated between France and the United 
405 Kingdom in the context of the Bay of Granville (in the Channel). Fishermen from Jersey and

406 France succeeded in resolving their historic conflicts by concluding such an agreement in

4072000 ratified in 2004. This is based on the possibility (under certain conditions) for fishermen

408 to access fishing areas located in or near the territorial waters of either nation. Application of

409 this treaty is placed under the control of a Joint Advisory Committee of the Bay of Granville,

410 composed of representatives of fishermen, officials and scientists from each state [51]. In the

411 case of Spanish fisheries in the southern Bay of Biscay, their management is slightly different

412 from France. There is an overlap of competences in Spanish territorial waters between the

413 Spanish government, the Basque government (Autonomous Regional Authority) and the

414 Fishermen Guild Organizations, the Cofradias [30]. In 1992, the fishermen of the two nations

415 were able to reach an agreement to end their conflicts about fishing for anchovy known as the

416 "Accord d"Arcachon"; it introduced a quota exchange and included restricted seasons for the

417 fleets of both countries [30,52,53]. The extension of such an area into the EEZ raises the

418 question of its legal status, its control and also its scientific monitoring.

419 As Forcada et al. [54] point out, efficient management needs a better understanding of

420 the dynamics of artisanal fisheries, the conservation of key habitats and the study of

421 interactions with other activities. A multidisciplinary and cross-border project with strong

422 involvement of French and Spanish stakeholders is in progress in order to improve knowledge

423 and optimize management of this cross-border area.

424 


\section{Acknowledgements}

426 This work was done in the context of the LOUPE and SYNTAX research projects. Thanks to

427 financial support from Conseil Général des Landes, Conseil Général des Pyrénées

428 Atlantiques, the Aquitaine Region, the French State, EU funds (EFF) and the local fishing

429 committee CIDPMEM Pyrénées Atlantiques Landes. We also thank the fishermen of St Jean

430 de Luz and Capbreton for their participation and their interest in our research projects. A

431 special thanks to B. Sarfas and V. Albistur for their help in English. We also thank the

432 reviewer and the editor for their useful comments on the submitted manuscript.

433

434

435

436

\section{References}

[1] Boersma PD, Parrish JK. Limiting abuse: marine protected areas, a limited solution. Ecological Economics 1999; 31: 287-304.

[2] Botsford LW, Kaplan DM, Hastings A. Sustainability and yield in marine reserve policy. American Fisheries Society Symposium 2004; 42: 75-86.

[3] Simonetta F, Claudet J, Grorud-Colvert K. Transitioning from single-sector management to ecosystem-based management: what can marine protected areas offer ? In: Claudet J. (Ed.) Marine protected areas-A Multidisciplinary Approach. Cambridge University Press -Ecology, Biodiversity and Conservation Series, Cambridge, UK, 2011; 11-34.

[4] Claudet J, Guidetti P, Mouillot D, Shears NT, Micheli F. Ecological effects of marine protected areas : conservation, restoration, and functioning. In: Claudet J. (Ed.) Marine protected areas-A Multidisciplinary Approach. Cambridge University Press-Ecology, Biodiversity and Conservation Series, Cambridge, UK, 2011; 37-71.

[5] Kaplan DM, Botsford LW, Jorgensen S. Dispersal per recruit: an efficient method for assessing sustainability in marine reserve networks. Ecological Applications 2006; 16: 2248-2263. 
450 [6] ICES. Report of the study group for the development of fishery-based forecasts. ICES

451 Document CM 2003/ACFM: 08 Ref; 2003.

452 [7] Delayat S, Legrand V. MAIA - Marine protected areas in the Atlantic arc. Les

453 cantonnements de pêche: 1. Diagnostic général sur la façade Manche Atlantique

454 française, Field study report; 2011.

455 [8] Daurès F, Rochet MJ, Van Iseghem S and Trenkel V. Fishing fleet typology, economic 456 dependence, and species landing profiles of the French fleets in the Bay of Biscay, 2000457 2006. Aquatic Living Resources 2009; $22: 535-547$.

458 [9] Le Masson du Parc F. Procès Verbaux des visites faites par ordre du Roy concernant la 459 pesche en mer in Pêches et Pêcheurs Du Domaine Maritime Aquitain, au XVIII ${ }^{\mathrm{e}}$ siècle, 460 Amirautés de Bayonne et de Bordeaux, Les Éditions de 1entre-deux-Mers 2000; 1727.

461 [10] Ferrer L, Fontán A, Mader J, Chust G, González M, Valencia V, Uriarte A, Collins MB. 462 Low-salinity plumes in the oceanic region of the Basque Country. Continental Shelf $463 \quad$ Research 2009; 29(8): 970-984.

464 [11] Batifoulier F, Lazure P, Velo-Suarez L, Maurer D, Bonneton P, Charria G, Dupuy C, 465 Gentien P. Distribution of Dinophysis species in the Bay of Biscay and possible transport 466 pathways to Arcachon Bay, Journal of Marine Systems 2013; 109-110: S273-S283.

467 [12] Rubio A, Fontan A, Lazure P, Gonzalez M, Valencia V, Ferrer L, Mader J, Hernandez C. 468 Seasonal to tidal variability of currents and temperature in waters of the continental slope, 469 southeastern Bay of Biscay, Journal of Marine Systems 2013; 109-110: S121-133.

470 [13] Anschutz P, Jorissen FJ, Chaillou G, Abu-Zied R, Fontanier C. Recent turbidite 471 deposition in the eastern Atlantic: Early diagenesis and biotic recovery. Journal of Marine $472 \quad$ Research 2002; 60: 835-854. 
[14] Hess S, FJ Jorissen. Distribution patterns of living benthic foraminifera from CapBreton canyon, Bay of Biscay: faunal response to sediment instability. Deep-Sea Research I 2009; 56: 1555-1578.

[15] DElbée J, Castège I, Hémery G, Lalanne Y, Mouches C, Pautrizel F, DAmico F. Variation and temporal patterns in the composition of the surface ichthyoplankton in the southern Bay of Biscay (W. Atlantic). Continental Shelf Research 2009; 29: 1136-1144.

[16] Nogueira E, Batle JM, Cabal J, Gonzalez-Nuevo G, Revilla R, Alvarez E, Bueno J. Accumulation of northern krill (Meganyctiphanes norvegica) in a convergence zone at the CapBreton Canyon (southern Bay of Biscay). Revista de Investigacion Marina 2008; 3: $225-226$.

[17] Aguirrezabalaga F, Carrera-Parra LF. Lumbrineridae (Polychaeta) from the Capbreton Canyon (Bay of Biscay, NE Atlantic) with the description of two new species. Scientia Marina 2006; 70(3): 17-25.

[18] Albaina A, Irigoien X. Zooplankton communities and oceanographic structures in a highresolution grid in the south-eastern corner of the Bay of Biscay. Estuarine and Coastal Shelf Science 2007; 75: 433-446.

[19] Reveillaud J, Freiwald A, Van Rooij D, Le Guilloux E, Altuna A, Foubert A, Vanreusel A, Olu-le Roy K, Henriet JP. The distribution of scleractinian corals in the Bay of Biscay, NE Atlantic. Facies 2008; 54: 317-331.

[20] Valeiras X, Abad E, Serrano A, Preciado I, Sánchez F. Distribution and abundance of seabirds at fishing boats in Galician and Cantabrian waters in relation to environmental and fisheries factors and discards. Actas X Symposium on Oceanography of the Bay of Biscay, Vigo; 2007.

[21] Castège I, Hémery G (coords). Oiseaux marins et cétacés du golfe de Gascogne Répartition, évolution des populations et éléments pour la définition des aires marines 
protégées. Biotope, Mèze ; Muséum National dHistoire Naturelle, Paris, (collection

499 Parthénope); 2009.

500 [22] Vetter EW, Dayton PK. Organic enrichment by macrophyte detritus and abundance

501 patterns of megafaunal populations in submarine canyons. Marine Ecology-Progress

$502 \quad$ Series 1999; 186: 137-148.

503 [23] De Leo FC, Smith CR, Rowden AA, Bowden DA, Clark MR. Submarine canyons:

504 hotspots of benthic biomass and productivity in the deep sea. Proceedings of the Royal of $505 \quad$ Society B 2010; 277: 2783-2792.

506 [24] Bremec C, Schejter L. Benthic diversity in a submarine canyon in the Argentine sea. 507 Diversidad bentónica en un cañón submarino en el mar argentine. Revista Chilena de $508 \quad$ Historia Natural 2010; 83: 453-457.

509 [25] Sanchez F, and Gil J. Hydrographic mesoscale structures and Poleward Current as a 510 determinant of hake (Merluccius merluccius) recruitment in the southern Bay of Biscay.

$511 \quad$ ICES Journal of Marine Science 2000; 57: 152-170.

512 [26] Leblond E, Merrien C. Synthèse des pêcheries dans les rectangles statistiques 15E8, 513 16E8, 16E7 - Année 2008. Ifremer SIH; 2010.

514 [27] Leblond E., Daurès F., Berthou P., Dintheer C. The Fisheries Information System of 515 Ifremer: a multidisciplinary monitoring network and an integrated approach for the 516 assessment of French fisheries, including small-scale fisheries. ICES CM 2008/K: 11;

518 [28] Leonardi S, Gallet F, Lesueur M. Etude du poids socio-économique de la filière pêche 519 dans le quartier maritime de Bayonne. Rapport CLPMEM de Bayonne; 2008.

520 [29] Le Tixerant M. Cartographie de la réglementation des pêches professionnelles-Régions Aquitaine et Poitou-Charentes; 2006. 
523 [30] Laborde S. Les pêches maritimes basques entre déclin et recomposition. Thèse, Univ. De $524 \quad$ Nantes; 2007.

525 [31] Delaunay JM. Méfiance cordiale, les relations franco-espagnoles de la fin du XIXème 526 siècle à la Première Guerre Mondiale. Volume 1 Les relations métropolitaines. Edition $527 \quad$ L'Harmattan; 2010.

528 [32] Touscoz J, Voisin PF. Les conventions internationales conclues par la France et publiées 529 au Journal Officiel de la République Française en 1967. In: Annuaire français de droit $530 \quad$ international 13: 782-801; 1967.

531 [33] Epalza M. Le magazine des jeunes pêcheurs basques nº/1999. Altxa Mutillak Spécial 532100 ans de pêche, attantzaleen 100 urteak; 1999.

533 [34] Fournet P. Le chalutage pélagique dans les eaux côtières du sud-ouest de la France. In: $534 \quad$ Norois $1980 ; 106: 277-287$.

535 [35] Lê S, Josse J, Husson F. FactoMineR: an R package for multivariate analysis. Journal of $536 \quad$ Statistical Software 2008; 25(1): 1-18.

537 [36] Ojeda-Martinez C, Bayle-Sempere JT, Sanchez-Perez P, Salas F, Stobart B, Goñi R, 538 Falcon JM, Graziano M, Guala I, Higgins R, Vandeperre F, Le Direach L, Martin-Sosa P, 539 Vaselli S. Review of the effects of protection in marine protected areas: current $540 \quad$ knowledge and gaps. Animal Biodiversity and Conservation 2011; 34(1): 191-203.

541 [37] Osenberg CW, Shima JS, Miller SL, Stier AC. Assessing effects of marine protected 542 areas: confounding in space and possible solutions. In: Claudet J. (Ed.) Marine protected 543 areas-A Multidisciplinary Approach. Cambridge University Press-Ecology, Biodiversity $544 \quad$ and Conservation Series, Cambridge, UK, 2011; 143-167.

545 [38] Stenzenmüller V, Pinnegar JK. Monitoring fisheries effects of marine protected areas: 546 current approaches and the need to integrated assessments. In: Claudet J. (Ed.) Marine 
protected areas-A Multidisciplinary Approach. Cambridge University Press-Ecology, Biodiversity and Conservation Series, Cambridge, UK, 2011; 168-189.

[39] Steinmetz F, Thebaud O, Blanchard F, Le Floch P, Bihel J. A bio-economic analysis of long term changes in the production of French fishing fleets operating in the Bay of Biscay. Aquatic Living Resources 2008; 21(3): 317-327.

[40] Coleman FC, Baker PB, CC Koenig. A review of gulf of Mexico marine protected areas. Fisheries 2004; 29(2): 10-21.

[41] Suuronen P, Jounela P, Tschernij V. Fishermen responses on marine protected areas in the Baltic cod fishery. Marine Policy 2010; 34: 237-243.

[42] Mangi SC, Rodwell LD, Hattam C. Assessing the impacts of establishing MPAs on fishermen and fish merchants: the case of Lyme Bay, UK. Ambio 2011; 40: 457-468.

[43] Mascia MB and Claus CA. A property rights approach to understanding human displacement from protected areas: the case of marine protected areas. Conservation

[44] Agardy T, Di Sciara GN, Christie P. Mind the gap: addressing the shortcomings of marine protected areas through large scale marine spatial planning. Marine Policy 2011; 35: 226-232.

[45] Garcia-Rodriguez M, Fernandez AM, Esteban A. Characterisation, analysis and catch rates of the small-scale fisheries of the Alicante Gulf (SE Spain) over a 10 years ${ }^{e e}$ time series. Fisheries Research 2006; 77: 226-238.

[46] Maynou F, Recasens L, Lombarte A. Fishing tactics dynamics of a Mediterranean smallscale coastal fishery. Aquatic Living Resources 2011; 24: 149-159.

[47] ICES. Report of the working group on the assessment of southern shelf stocks of Hake, Monk, and Megrim (WGHMM), 5-11 May 2011, ICES Headquarters, Copenhagen. 
572 [48] Le Floc'h P, Poulard JC, Thébaud O, Blanchard F, Bihel J, Steinmetz F. Analyzing the market position of fish species subject to the impact of long-term changes: a case study of French fisheries in the Bay of Biscay. Aquatic Living Resources 2008; 21: 307-316.

[49] Duhamel du Monceau HL. Traité général des pesches et histoire des poissons qu'elles fournissent tant pour la subsistance des hommes que pour plusieurs autres usages qui ont rapport aux arts et au commerce. Collection Pêche Marine, Réédition 1769; 1988.

578 [50] Arregi L, A Bilbao, Galparsoro I. Descripción de la tipología de oficios de pesca actuales de la pesca artesanal costera. Proyecto RP 2003 015; Informe final; 2004.

[51] Fleury C. Jersey and Guernsey: Two distinct approaches to cross-border fishery management. Shima: The International Journal of Research into Island Cultures 2011; 5(1): 24-43.

583 [52] Astorkiza K. Fisheries policy and the Cofradias in the Basque country: the case of Albacore and Anchovy. Papeles de Economía Española; 1998.

[53] Curtin R., Martinet V. Viability of transboundary fisheries and international quota sharing: the case of the Bay of Biscay Anchovy. GERAD’s Joint Seminars; 2011.

587 [54] Forcada A, Valle C, Sanchez-Lizaso JL, Bayle-Sempere JT, Corsi F. Structure and spatio-temporal dynamics of artisanal fisheries around a Mediterranean marine protected area. ICES Journal of Marine Science 2010; 67: 191-203. 


\section{Figure Captions}

592 Fig. 1. a) Introduction in 1985 of restricted area for gillnets (1 $\left.305 \mathrm{~km}^{2}\right)$. The pelagic trawlers 593 are prohibited in the 3 miles limits.

594 Fig. 1. b) In 1993, additional prohibition was introduced in the 6 miles limit of for pelagic and 595 bottom trawlers. In 1999, the restricted area for gillnets decreased to $332 \mathrm{~km}^{2}$.

596 Fig. 2. Evolution of active vessels number at least once by rectangle (in \%). The total number 597 of vessels is mentioned on the right side in italic.

598 Fig. 3. Evolution of active vessels number by métier in the study area.

599 Fig. 4a. PCA Analysis: correlation circle and individuals plot on axis Dim1 and Dim2. The 600 contribution of species in the turnover are presented : ALB $=$ albacore; HAK $=$ hake; $\mathrm{SAR}=$ 601 sardine; $\mathrm{MAC}=$ common mackerel; MAC_ESP $=$ spanish mackerel; THU $=$ tuna. Métiers 602 and sectors are added as supplementary factors.

603 Fig. 4b. PCA Analysis: correlation circle and individuals plot on axes Dim2 and Dim3. The 604 contribution of species in the turnover are presented: $\mathrm{ALB}=$ albacore; $\mathrm{HAK}=$ hake; $\mathrm{SOL}=$ 605 common sole; THU = tunas. Métiers and sectors are added as supplementary factors.

606 Fig. 5. Contribution of 4 main species to turnover, in percentage a) for bottom longliners, b) 607 for gillnetters, c) for pelagic trawlers, d) for bottom trawlers

608 Fig. 6. Evolution of turnover by vessel by crew member for main métiers in R16E8 (in k€ 609 constant). 
$611 \quad$ Fig.1 a

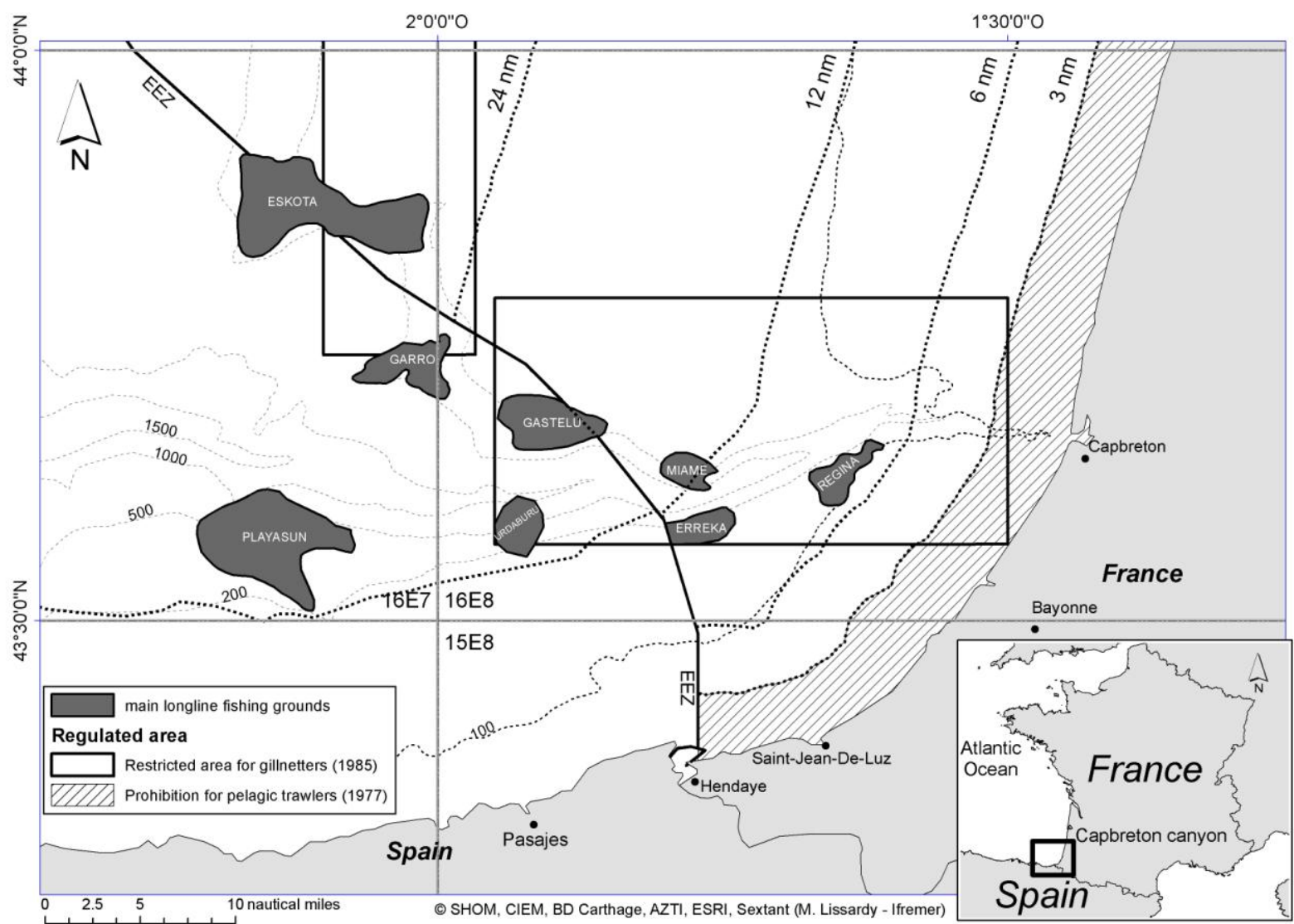

613 
Fig. $1 \mathrm{~b}$

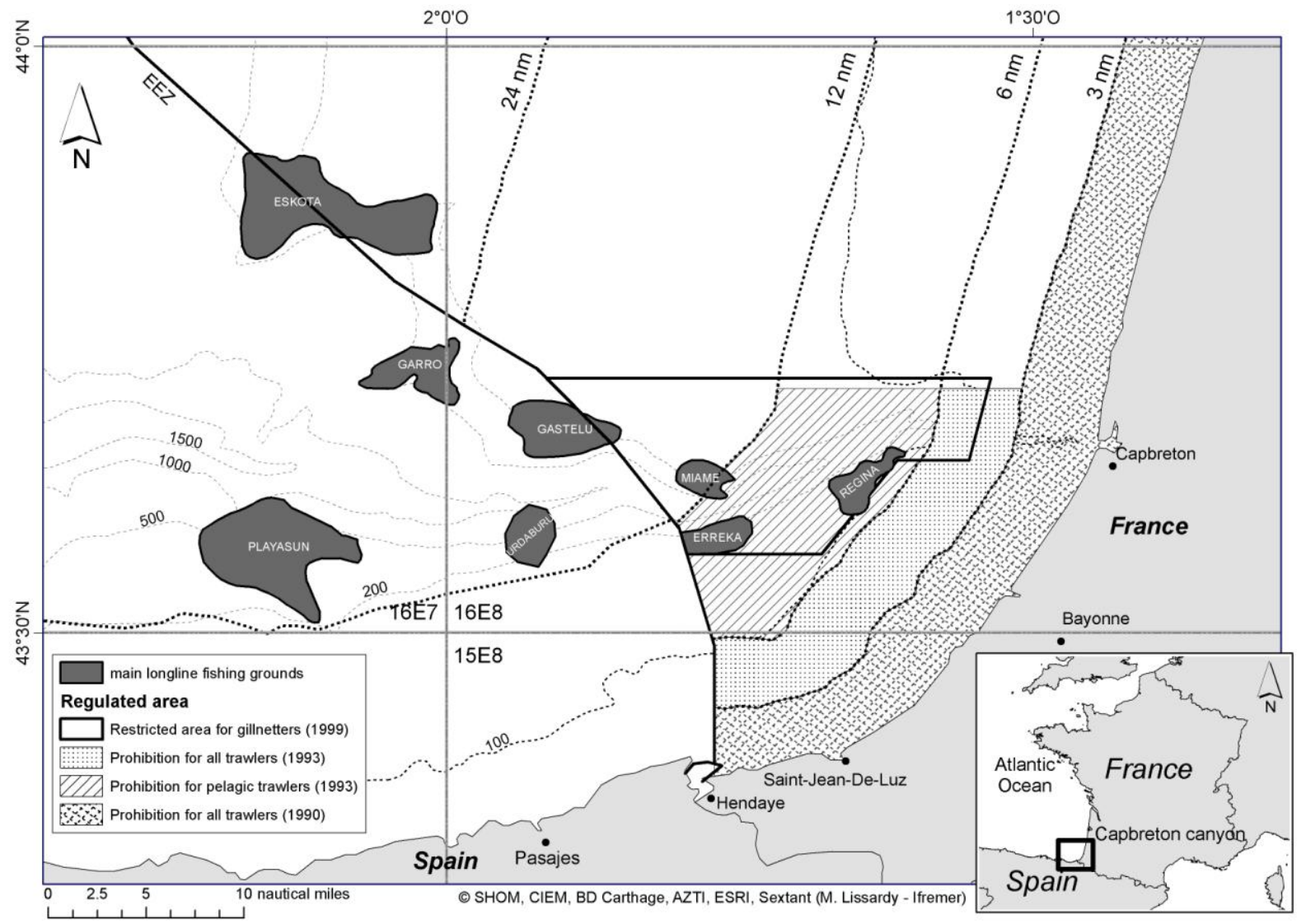

615

616 
617 Fig. 2

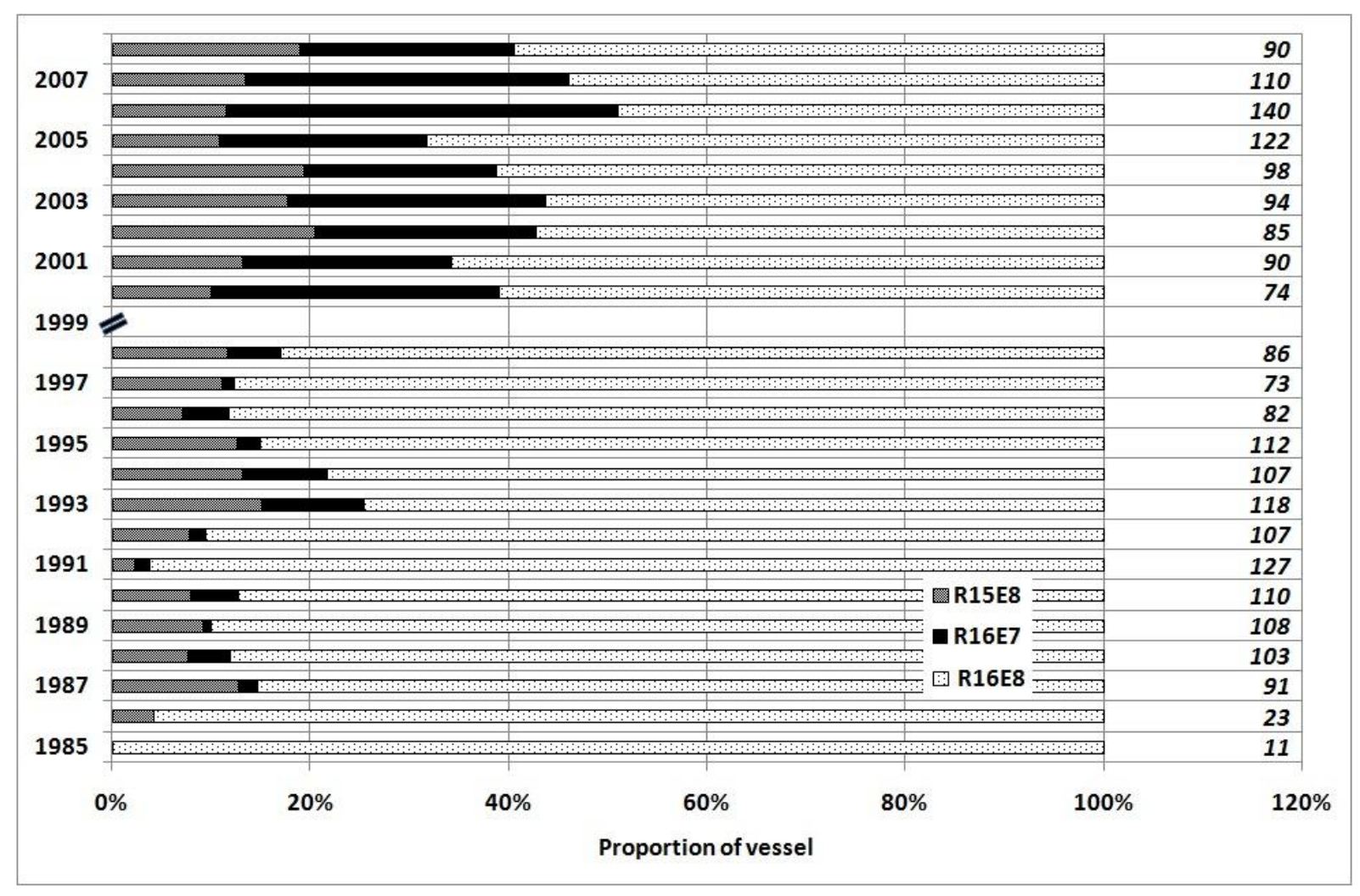

619 
$620 \quad$ Fig. 3

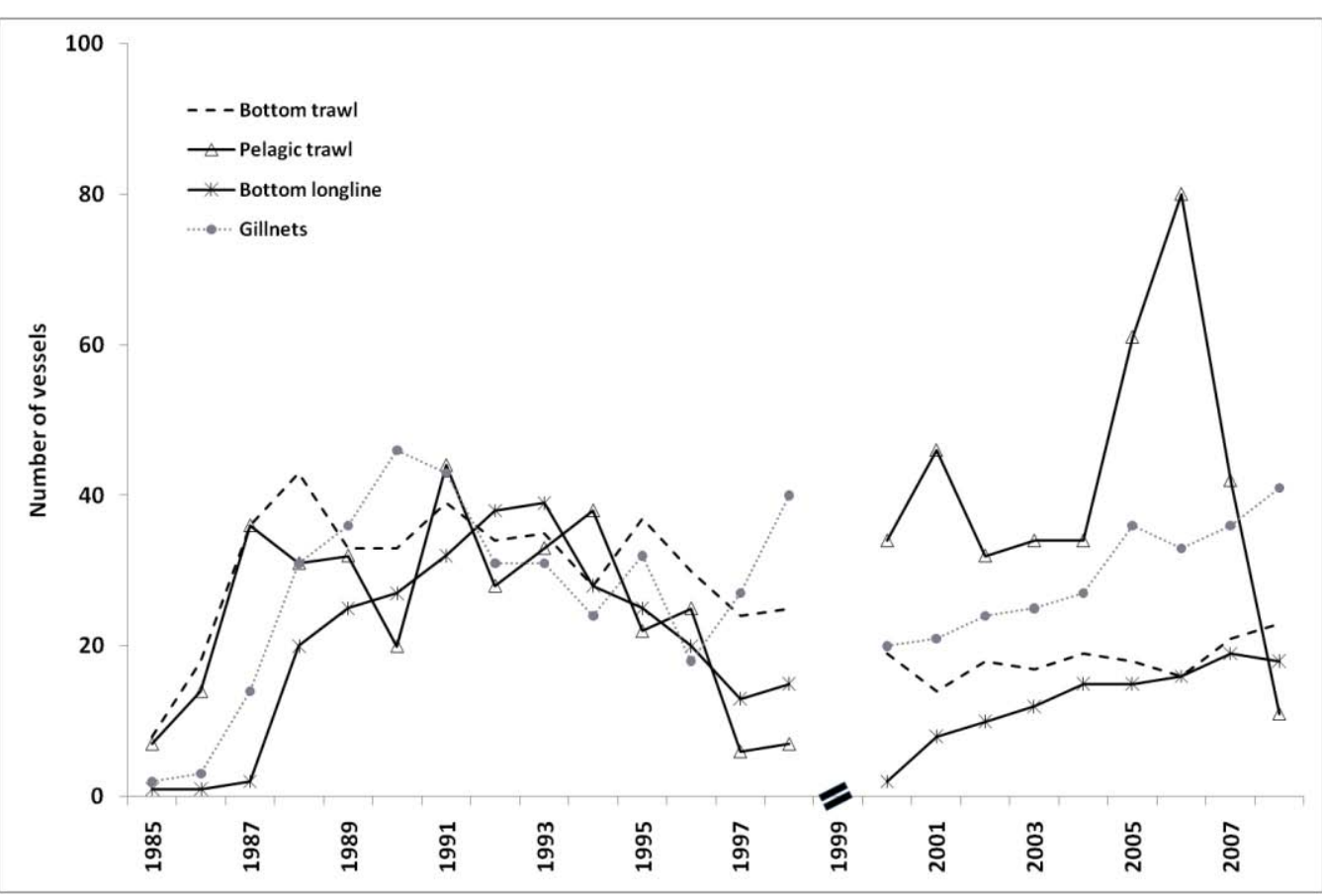

622

623

624 
Fig. 4
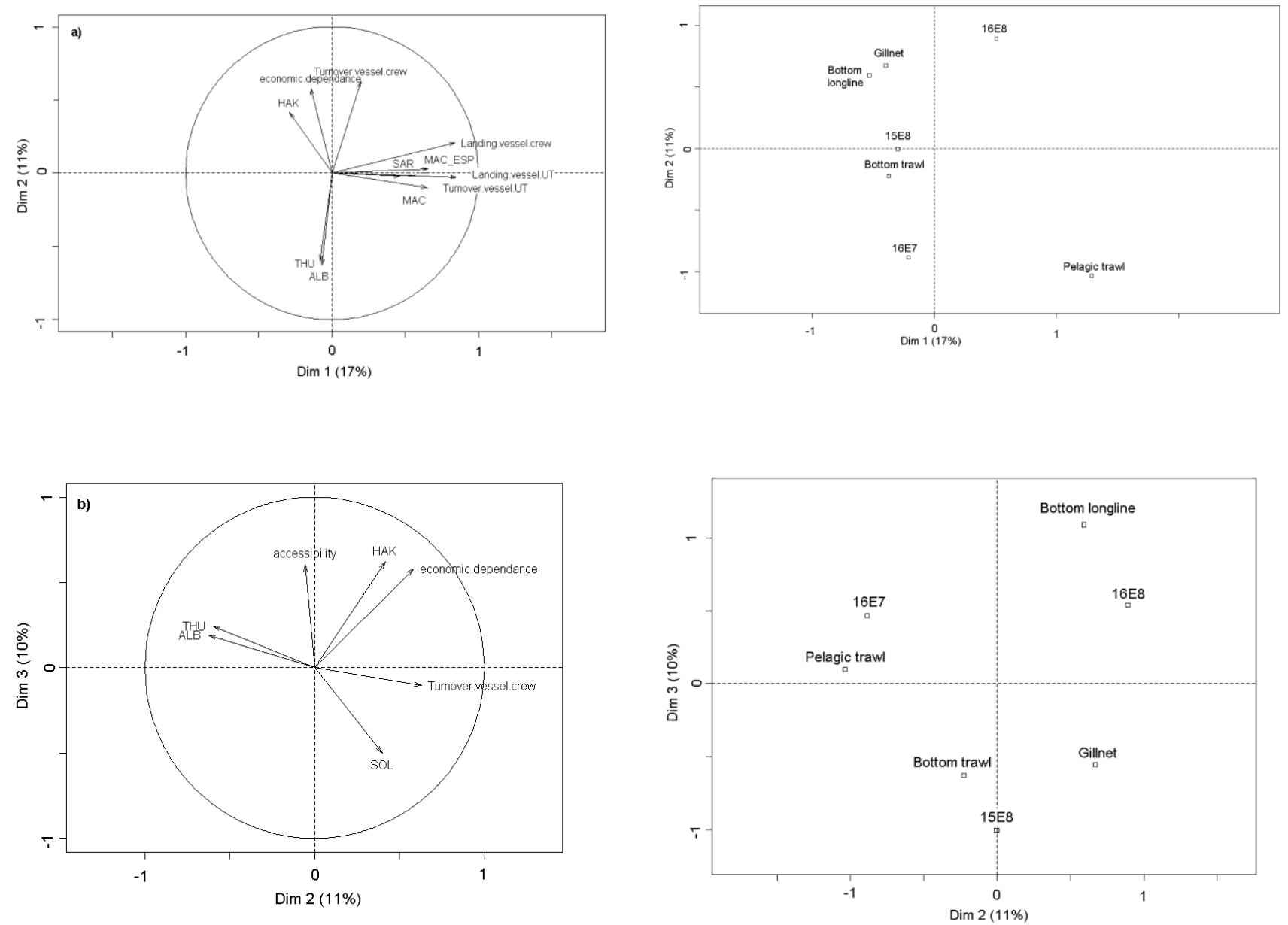

626

627

628

629 
630

Fig. 5

631
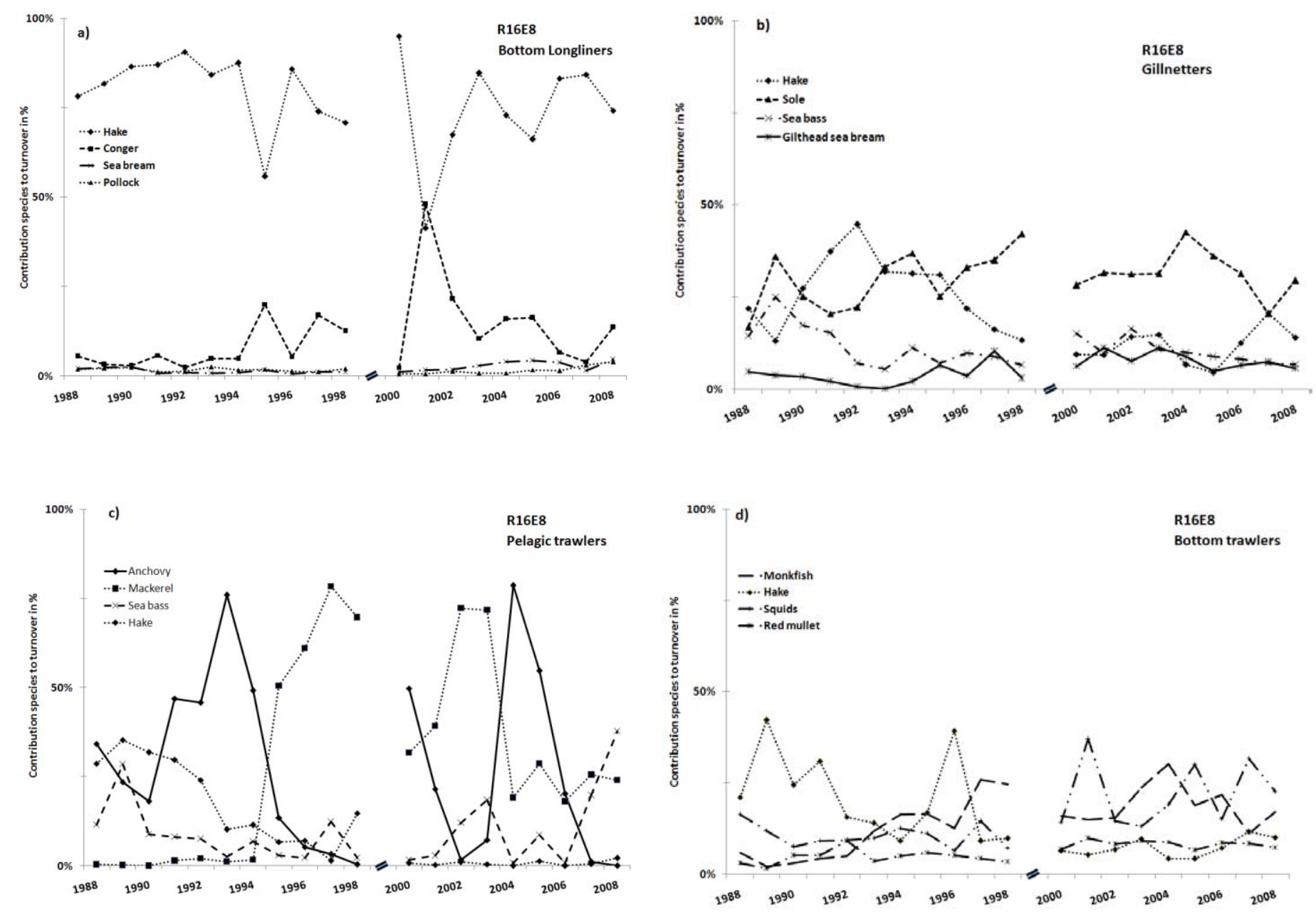

632

633

32 
634 Fig. 6

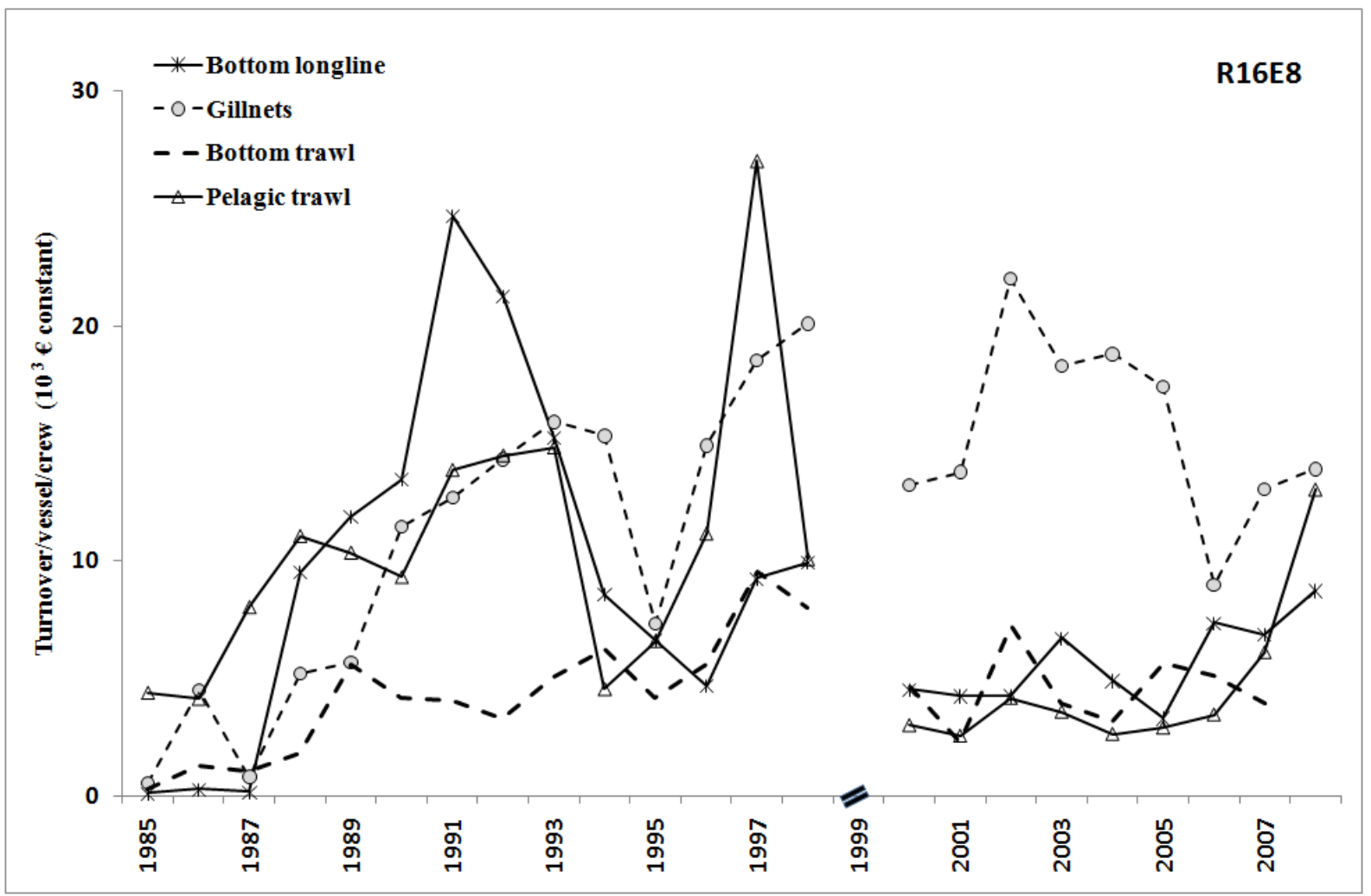

636 


\section{Tables}

638 Table 1. Characteristics of métiers operating in the southern part of the Bay of Biscay.

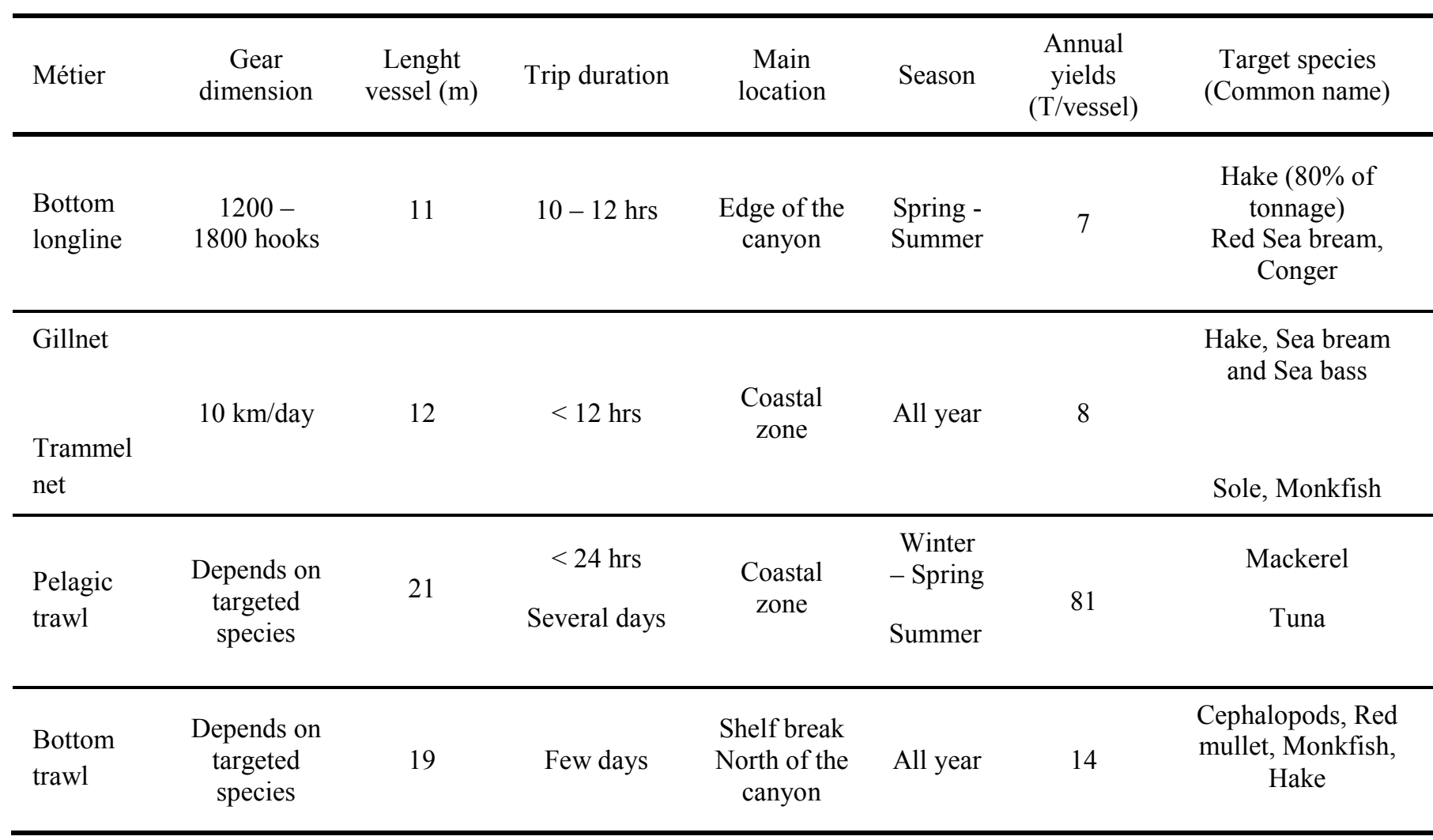

639

640 
642 Table 2. Regulatory framework in the southern part of the Bay of Biscay [29].

\begin{tabular}{|c|c|c|c|c|c|c|c|}
\hline & Subject & Area & Origin & Date & $\begin{array}{l}\text { Type of } \\
\text { regulation }\end{array}$ & $\begin{array}{l}\text { Gear, Fleets } \\
\text { concerned }\end{array}$ & Exemption \\
\hline \multirow{7}{*}{ 䔍 } & $\begin{array}{l}\text { Prohibition Inside } 3 \\
\text { miles }\end{array}$ & VIII ab & $\begin{array}{l}\text { Fisheries } \\
\text { Depart. } \\
\text { (DPMA) }\end{array}$ & $\begin{array}{l}3 \text { Mar. } \\
1977\end{array}$ & Ord. $\mathrm{n}^{\circ} 1248$ & Pelagic trawl & \\
\hline & $\begin{array}{l}\text { Prohibition Inside } 6 \\
\text { miles \& } \\
\text { South } 43^{\circ} 42^{\bullet} 5 \mathrm{~N}\end{array}$ & $\begin{array}{l}16 \mathrm{E} 8 \\
15 \mathrm{E} 8\end{array}$ & $\begin{array}{c}\text { Director of } \\
\text { Maritime } \\
\text { Affairs } \\
\text { Bayonne } \\
\end{array}$ & $\begin{array}{l}27 \text { Apr. } \\
1981\end{array}$ & Ord. $n^{\circ} 88$ & $\begin{array}{c}\text { Pelagic trawl } \\
\text { Bottom trawl } \\
\text { Pelagic net }\end{array}$ & Engine power $<150 \mathrm{CV}$ \\
\hline & Maritime border & $\begin{array}{l}\text { EEZ } \\
\text { Bay of } \\
\text { Biscay. }\end{array}$ & Government & $\begin{array}{l}10 \text { Dec. } \\
1982\end{array}$ & Convention & All fleets & \\
\hline & $\begin{array}{l}\text { Restricted area } \\
1305 \mathrm{~km}^{2}\end{array}$ & $\begin{array}{l}16 \mathrm{E} 8 \\
16 \mathrm{E} 7 \\
17 \mathrm{E} 7 \\
17 \mathrm{E} 8\end{array}$ & Prefecture & $\begin{array}{l}5 \text { Mar. } \\
1985\end{array}$ & Ord.n $n^{\circ} 40$ & Nets & \\
\hline & $\begin{array}{l}\text { Restricted area around } \\
\text { landing buoy } 0.8 \mathrm{~km}^{2}\end{array}$ & $16 \mathrm{E} 8$ & Prefecture & $\begin{array}{c}31 \mathrm{Jul} . \\
1989 \\
\end{array}$ & $\begin{array}{l}\text { Ord. } n^{\circ} \\
68 / 89 \\
\end{array}$ & Passive gears & Other gears \\
\hline & $\begin{array}{l}\text { Prohibition Inside } 6 \\
\text { miles \& } \\
\text { South } 43^{\circ} 42^{\text {ee }} 5 \mathrm{~N}\end{array}$ & $16 \mathrm{E} 815 \mathrm{E} 8$ & $\begin{array}{l}\text { Secretariat } \\
\text { of State }\end{array}$ & $\begin{array}{l}8 \text { Feb. } \\
1993\end{array}$ & Ord. $n^{\circ} 21$ & Bottom trawl & No more \\
\hline & $\begin{array}{l}\text { Restricted area } \\
332 \mathrm{~km}^{2}\end{array}$ & $16 \mathrm{E} 8$ & Prefecture & $\begin{array}{l}23 \text { Jun. } \\
1999\end{array}$ & $\begin{array}{c}\text { Ord } \\
\mathrm{n}^{\circ} 156 / 99\end{array}$ & Nets & $\begin{array}{l}\text { Except foreign vessels } \\
\text { outside French territorial } \\
\text { waters - area of } 115 \mathrm{~km}^{2}\end{array}$ \\
\hline \multirow{4}{*}{ 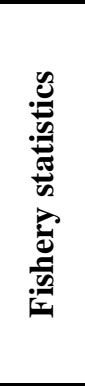 } & Logbook & EEZ & EEC & $\begin{array}{c}29 \text { Jun. } \\
1982 \\
\end{array}$ & $\begin{array}{c}\text { Reg. EC } \\
\mathrm{n}^{\circ} 2057 \\
\end{array}$ & $\begin{array}{l}\text { All European } \\
\text { vessels }\end{array}$ & $\begin{array}{l}\text { Vessel size }>10 \mathrm{~m} \&<17 \\
\mathrm{~m} \& \text { trip duration }<24 \mathrm{~h}\end{array}$ \\
\hline & $\begin{array}{l}\text { Obligation to report } \\
\text { catches }\end{array}$ & EEZ & Ministry & $\begin{array}{c}26 \text { Apr. } \\
1989 \\
\end{array}$ & $\begin{array}{c}\text { Dec. } \\
\mathrm{n}^{\circ} 89 / 2773 \\
\end{array}$ & $\begin{array}{l}\text { All French } \\
\text { vessels }\end{array}$ & \\
\hline & Catch reports & EEZ & Ministry & $\begin{array}{c}18 \mathrm{Jul} \\
1990\end{array}$ & Ord. n²091 & $\begin{array}{c}\text { All French } \\
\text { vessels }< \\
10 \mathrm{~m} \\
\end{array}$ & \\
\hline & Logbook & EEZ & EEC & $\begin{array}{c}12 \text { Oct. } \\
1993 \\
\end{array}$ & $\begin{array}{l}\text { Reg. EEC n }{ }^{\circ} \\
2847 \\
\end{array}$ & $\begin{array}{c}\text { All European } \\
\text { vessels }\end{array}$ & Vessel size $<10 \mathrm{~m}$ \\
\hline \multirow{2}{*}{ 豙 } & $\begin{array}{l}\text { Operation Permit } \\
\text { Implementation }\end{array}$ & & Ministry & $\begin{array}{l}\text { 8 Jan. } \\
1993 \\
\end{array}$ & Dec. $n^{\circ} 99 / 33$ & $\begin{array}{l}\text { All French } \\
\text { vessels }\end{array}$ & \\
\hline & Driftnet prohibiting & EEZ & EEC & $\begin{array}{l}8 \text { Jun. } \\
1998\end{array}$ & $\begin{array}{l}\text { Reg EC n } \\
894 / 97\end{array}$ & $\begin{array}{l}\text { All European } \\
\text { vessels }\end{array}$ & \\
\hline \multirow{4}{*}{ 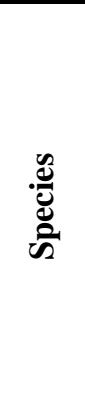 } & Protection plan hake & VIII abcd & EEC & $\begin{array}{c}14 \text { Jun. } \\
2001\end{array}$ & $\begin{array}{c}\text { Reg. EC } \\
1162 / 2001 \\
2602 / 2001 \\
\& 494 / 2002\end{array}$ & $\begin{array}{l}\text { All European } \\
\text { vessels }\end{array}$ & \\
\hline & Protection plan anchovy & VIII & EEC & $\begin{array}{l}\text { 1 Jul. } \\
2005 \\
\end{array}$ & $\begin{array}{c}\text { Reg. EC } \\
1037 \\
\end{array}$ & $\begin{array}{l}\text { All European } \\
\text { vessels }\end{array}$ & Duration 3 months \\
\hline & Sole fishing license & VIII ab & EEC & $\begin{array}{c}23 \text { Jun. } \\
2006\end{array}$ & $\begin{array}{c}\text { Reg. EC } \\
388 / 2008 \\
\end{array}$ & $\begin{array}{l}\text { All French } \\
\text { vessels }\end{array}$ & $\begin{array}{c}\text { Landings }<2 \text { t.year }^{-1} \text { or }< \\
100 \mathrm{~kg} \text {.day }\end{array}$ \\
\hline & $\begin{array}{l}\text { Anchovy fishery } \\
\text { closure }\end{array}$ & VIIIIabc & EEC & $\begin{array}{l}11 \text { Jun. } \\
2006\end{array}$ & $\begin{array}{l}\text { Reg. EC } \\
1116\end{array}$ & $\begin{array}{l}\text { All European } \\
\text { vessels }\end{array}$ & \\
\hline
\end{tabular}


644 Table 3. Maritime surface of rectangle and Spanish territorial waters (in $\mathrm{km}^{2}$ ). Prohibited 645 maritime surface by gear concerned for the French vessels are mentioned (in $\mathrm{km}^{2}$ and in 646 percentage of total area).

\begin{tabular}{|c|c|c|c|c|c|}
\hline \multirow{2}{*}{\multicolumn{2}{|c|}{ Maritime surface $\mathrm{km}^{2}$}} & 15E8 & $16 E 7$ & $16 \mathrm{E8}$ & Total \\
\hline & & 463.3 & 4473.4 & 2535.3 & 7474.1 \\
\hline \multicolumn{2}{|c|}{$\begin{array}{l}\text { Spanish territorial waters } \\
\mathrm{km}^{2}\end{array}$} & 295 & - & 115 & $410(5.5 \%)$ \\
\hline Period & Gears & \multicolumn{4}{|c|}{ Prohibited surface in $\mathbf{k m}^{2}$} \\
\hline 1977 & Pelagic trawl & 402.9 & & 434.5 & $\begin{array}{c}837.4 \\
(11.2 \%)\end{array}$ \\
\hline 1981 & Pelagic trawl & 460.8 & & 580 & $\begin{array}{l}1040.8 \\
(13.9 \%)\end{array}$ \\
\hline 1981 & Bottom trawl & 460.8 & & 580 & 1040.8 \\
\hline 1993 & All trawls & 463.5 & & 831.7 & $\begin{array}{c}1295.2 \\
(17.4 \%)\end{array}$ \\
\hline 1982 & Longlines & 295 & & 115 & $\begin{array}{c}410 \\
(5.5 \%) \\
\end{array}$ \\
\hline 1989 & Longlines & 295 & & 115.8 & 410.8 \\
\hline 1985 & Gillnets & 295 & 238.6 & 950 & $\begin{array}{r}1483.6 \\
(19.8 \%) \\
\end{array}$ \\
\hline 1999 & Gillnets & 295 & & 332.8 & $\begin{array}{c}627.8 \\
(8.4 \%)\end{array}$ \\
\hline
\end{tabular}

647

648 